\title{
Kjemsgaards Saga.
}

\section{Af Olav Kjems, Postmester, Kobenhavu.}

Kjemsgaard (i Hygum Sogn i Nordslesvig) var Fostegaard under Gram Gods og nævnes derved i Jordebøger og Opgorelser vedrørende Godsets Bøndersteder, hvorved der i nogen Grad er Lejlighed til at følge Gaarden gennem Tiderne. I len (paa Tysk) i 1651 udkomme Landsbeskrivelse af de to Hertugdømmer Siesvig og Holsten af C. Danckwerth staar - forvansket anført Kempitgarde, og Værkets Kort viser »Kempingarde«. Men Gaarden kendes fra ældre Dokumenter.

I en Oversigt over Gram Gods's Besiddelser fra 1585 , optaget i Anledning af at Kong Frederik den 2. paatankte at købe Gram, angives de Ydelser, som Bønderne aarlig giver til codset for Brugen af deres Gaarde; her anfores under skovegnene:

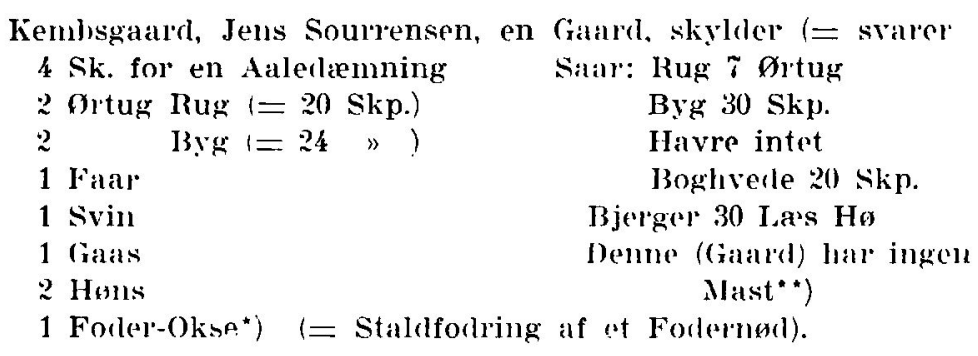

Medens de fleste Fæstegaarde tillige yder et kontant Pengebeløb, træcler for Kjemsgaard og nogle andre Korn i stedet.

Kjemsgaard ligger paa et Strøg, der har været Bespettelsesomraade fra Oldtiden, og der findes paa Kjemsgaards Mark en, desverre strerkt ødelagt, Langdysse som et direkte Udtryk herfor.

*) Studlene gik det 1'ste Aar om Sommeren paa Overdlevene og sattes om Vinteren paa Stall hos Bønderne; derefter ferledes de paa Stald, til de blev fede nok til Uilforsel syilpaa.

*) d. v. s. kan ikke have Svin paa Ohten. 
Ensomt synes der at maatte have været derude paa Hedlen, og selv om der ikke var Skov til Gaarden, var der saarlan i Nærherlen, og dér var baacle Ulve og Vildsvin. I Steens i Nabosognet Hjortlund klager saaledes en af Grans Fisteboncler $i$ 16if over, at en Del af hans Heste er sihielrefuen af den schadelig Ulf " og Forvalteren paa (iram meddeler i 16666 , at Bonderne nu og da lider stor Skade af Ulvene. I 1766 erklarer Prasten i Hygum: "Vilde Dyr er her som i andre Skovegne, raae-Dyr, Harer, Ulve, Ræve og Vildsvin, Grævling, Odder og Morer (= Maar), men Rotter ingen«. Og d. 11/3 1776 meldler l'orvalteren paa Gram, at sksnt der paa kort Tid er bleven nedagt 3 gamle C'lve af de kongelige Skovbetjente, er dog for 2 Nartter ciden 2 Kvier og et 1-Aars Fol blevet sonderrevet af lenne slags Dryr.

Ditlev v. Buchwald, der var Ejer af Gram i 1585 , vilde nodig sælge, fordi Godset var den bedste af hans Ejendomme, (han var Holstener og ejedle ogsaa Gods i Holsten), og der blev tla heller ingen Handel af.

Fra Sønnesønnen af samme Navı foreligger en Jordebog ('a. 1625), der om Kjemsgaard (paa Tysk) anforer:

Kempsgatard, en hel Gatard, giver skỵld i korn og iovrigt som folger:

20 Skp. liug

2 - Byg

1 svin eller

1 Faar -

1 H.ll.

1 Gaas -

2 Hons -

:2) $\mathrm{Eg} \mathrm{-}$

Vognpenge

Fodrer en Okse eller giver 1 Rill.

Ved denne Gaard gaar en La, hvori haves Fiskeri og Aale. dirmning. Denne Gaard har i nogle Aar virert ucllejet og har deraf givet ialt 20 i Rill. 32 sk.

Facit 3 Rill. 13 sk.

Nu kan der altsaa gives enten Penge eller Naturalier.

Der synes efter Jordebogens Ulitalelse at have været Vanskelighed med at holde Gaarden besat, se ogsaa senere, at $v$. 
Buchwald omkring 1636 har maattet drive Gaarden ved Godsets Folk. Men der kom endnu strengere Tider for Egnen: Svenskekrigen i 165\%, der hjemsøgte disse Landsdele haardt, og i $1659 \mathrm{P}$ e s t e $\mathrm{n}$; der findes imellem de mange Døde i Hygom Kirkebog, som begravet den 29/3 1659: "Hans Kjær af Kiemsgaard sampt et af hans Bornu. Da tilmed Polakkerne, der kom som Hjælpetropper for Danmark mod Svenskerne, huserede saa slemt som Fjender, flygtede Folk i disse Egne til Ribe i Massevis og blev der Sommeren over, hvilket bevirkede, at sygdommen rigtig kunde hærge. Ved Juletid 1659 opgør Præsten, efter Tilbagekomsten fra Ribe, i Kirkebogen, at der altsaa alene i Hygum Sogn - er bortkaldt 504 Personer af "den ny sygilom", som den hyppigst kaldtes (den kaldtes ogsaa Blodgang eller den hvide B!egsot); mellem de da landsbyvis indforte Navne findes ogsaa Hans Kjærsdatter af Kiemsgaard, og Gaarten er maaske herved igen blevet ubesat.

Egnen har ved denne Tid frembudt et sørgeligt Syn med mange forladte Bondergaarde, hvis Bygnninger var stærkt ramponerede, dels af Fjendehaand, dels ved Tyveri af Materialier, der kunde anvendes andetsteds, og af den mauglende Vedligeholdelse. Medvirkende var vel ogsaa, at Bønderne ligefrem romte bort for at undgaa det Hoveriarbejde paa Herskabets Marker, der var kommet $i$ forøget Brug. I Udtalelser fra omkring 1700 berettes om hin Tid, hvorledes "for den kort tilforn overstandne bedrøvelig Svendske- og straks derpaa følgende Krigstider, da mand ikke alleneste kunde faa Gaarle og Grund at bluge for saadan en ringe aarlig Afgift (som 12 Skp. Rug og 10 Skp. Byg for en stor (iaard), men elldogsaa paa nogle Aar med Frihed (for Afgifter), at Gaardene skulde blive her og der i Landene bebygt og beboet«, hvorledes adskillige Marker ikke blev dyrket, men at man »i de efterfølgende Aar lod dem ligge under Fæfod«,og at "enhver slog Græs efter Krigstiden i de Tider, der de var kommen hjem til deres Huse igen, hvor de lystede. og bedst kunde afstedkomme» (altsaa uanset om det var deres egen Jord eller ej). 
leltherren Haus Schack havde kastet sine Øjue paa Gram i Begyudelsen af 16ti0'erne og havde til Orientering udsendt Folk, der skulle undersoge Godsets Tilstand; for Skovenes og Bumblerstederues Vedkommende var det Amtsskriveren i Ribe Wihheln Brockmann, der $\mathrm{i}$ al Hemmelighed paa det nøjeste ved Selvsyn bedomte og udspurgte - og derefter afgav sin Berotuing om den «s tore Ja m mer«, dateret 4/10 1663; heri staar:

Kimlsgand: Er an Enegand, der ligger alene paa Marken

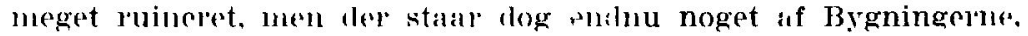
let meste ar nedfalilet, noget Trandark fincles enclnu paa Stedet. Iovrigt var af 86 ( iaarie og Hu<e, som Beretningen omfattor, kun 7 besat, Resten laa øde. Hans schack købte Godset i 1166k og gik i Gang med at faa Forholıene i Skik, opkobte en Del Bondergods (de saakaldte "Nỵe (irammer") for at faa sine Besidilelser bedre afrumblet, og sorgede for at faa de forladte Gaarde forsmet ned Bygninger og Folk. De sidste henteles ofte langvejs fra; en Del var afskedigede Soldater, og le fleste nye Fæstere maatte forsynes med alt "Klæaler og Sko, Ager, Kvag, Hus, Gaal'd og alt hvad dertil horer, undtagen Bmmene«, som Forvalteren udtrykker sig i et Brev til Felthel'rell.

If en Opgorelse fra 1668 ses, at over 50 af Gammelgrammer Halvgaarde var besat i Lobet af de 4 Aar. Hans Schack traf (len Bestemmelse, at Helgaardene skulde deles, idet ingen af de uyankomme maatte hesidde mere end en halv Gaard. Mellem de »øde« opfores Kempsgaard men med Bemarkning: 12 lag nyt Hus. Det, der skal ydes til Herskabet, opfores som i 1625 . Dong er tilkommet en ny Ylelse: Fæsteren skal aarlig spinde - Pund Hor eller 8 Pund Blaar til Herskabet; i Oktober 1669 medrleler Forvalterell, at han har fordelt 112 Pol. Hør og 150 Pot. Blaar til Spinding til Bonlerne, saavel de gamle som de nye (Grammer), skont mhine« ikke rigtig har villet gaa med dertil.

Der har varet stille paa Gaard og Marker, der vel kun Iar vieret benyttet af Markens vilde Dyr og Godsets Faar; $i$ 
Marts 1666 erklærer Forvalteren overfor Greven, at han vil drage Omsorg for, at de Faar, der var indkøbt, men som ikke var udleveret til Fæsterne, tilligemed en Faarehyrde sendes til Kempsgaard eller Alkjær, da begge Steder har Hede og Ager.

I Juni 1666 erindrer Hans Schack, der bor i Københarn, om, at der skal begyndes paa Ombrgningen af Kjemsgaard, og i Byggeregnskabet for Maj 1666 - Maj 1667 staar Kempsgaard opført med 12 Fag. Der var sluttet Kontrakt med en Bygmester om en Byggepris af $2 \mathrm{Rdl}$. 4 Sk. for hvert af de $171 \mathrm{Fag}$, (ler skulde bygges paa Bøndergaardene i nævnte Aar, hertiI kom Saveløn for de 26 Alen, der skulde til hvert Fag, og Tækiningen med Lyng og Straa; Bønderne skulde selv hjælpe til med Tækningen, men paa Kjemsgaard var der jo ingen Beboere, og dette er vel Grunden til, at den nye Forvalter et Par Aar efter (30/7 1669) kan meddele H. Schack, at paa Kjemsgaard er Huset endnu kun halvt bedækket. Det synes efter Brevet, som om Bondergaardene er længere tilbage, end Schack har faaet Indtryk af efter den forrige Forvalters Breve, paa mange Gaarde mangler adskillige Fag. Forvalteren foreslaar, at der skaffes Brædder fra Møgeltønder, der ejedes af $\mathrm{H}$. Schack. Han har antaget 2 Savere, men mangler en god Tømmermand, da den nuværende ikke er til megen Gavn paa Grund af Drikkeri. *)

Kjemsgaard synes først at være blevet b e s a t i 1673 , og da kun for den ene Halvgaard. For dette Aar anføres Peer Christensen med 12 Rdl. i Afgift, og efter Kirkebogen gifter han sig i 1674. Han nævnes i Kirkebogen stadig Peder Nielsen, i Godsregnskaberne derimod undertiden Peder Christensen. I Regnskabet for Tiden Philippi Jacobi Dag (= 1. Maj) 1679 til Aarsdagen 1680 anfores hans Afgift med 15 Rdl., hvorhos han har

*) Brændevin synes at have været en nødvendig Smørelse til Arbejdsfolk. I Sommeren 1679, da Gram Gods havde 6 Polakker i Arbejcle i Vesterlinnet i hvert Fald i 3 Maaneder, opførtes som daglig Udgift: 1 Rdl. i Arbejdsløn og 1 Mark sefter hans Højgrevelige Excellenses Befaling til Bræulevin«. 
leveret et Svin, og derfor er blevet godskrevet 1 Rdl. Desuden anføres under Indtagter for henlejet .Jord og Eng: "Annammet af Peder i Kinsgaard for en half odde Gaardtz Jord 8 Rdl.« Afgiften af Gaarden har altsaa været ialt 24 Rdl., formentlig beregnet efter 2 Halvgaarde à 12 Rdl. Den anden halve Gaard er vist først besat omkring 1683, for livilket Aar der i en Jordehog anfores 2 "Gaardbrødre» Peder Christensen og Th o in as: Kas mu s se n. Den sidstes Navn optreder ogsaa i Kirkebogen dette Aar. Han har været en Mand med store Born og synes at have været dygtigere end Peder Nielsen. Opgorelsen over Sxdekorn leveret til Bønderne i Misvækst-Aarene $1683-87$ synes at vise demne Forskel:

Trr. Skpr.

1. Maj 83 Peter Nielsen af Kempsganari, Rug à 9 sk.

4. Febr. 84 Rug paa Bofaling Byg

28. Juni Rug 11 Sk.

12. Maj 86 Boghvelle 8 sk.

1.). April 87 Rug

16. - Havre

25. - Rug

Boghvede

8\%: Thomas Rasmussen Rug

$\begin{array}{rr}2 & - \\ 2 & \\ - & 5 \\ 2 & - \\ 1 & - \\ -2 & - \\ 2 & - \\ 1 & - \\ 2 & -\end{array}$

og Thomas Rasmussen tilbagebetaler formentlig Laanet imlen 1. Maj 1688, da han afleverer 2 Tdr. 2 skpr. Byg. Derimorl ses P. Nielsen ikke at have tilbageleveret noget. Det navute Reguskab over Laanekorn til Bønderne er iovrigt et meget stort Regnskab, og flere af Bønderne er kommet dybt i Ga!ł, nogle er blevet sat fra Gaarden, en Del har betalt med Kreaturer (f. Eks.: en ung Oxe 4 (6) Rdl., en Kvie 5 Mark lybsk); en har udstedt en Obligation paa 18 Rall. 2 Sk, for 6 Tdr. 5 Skpr. 1 Fulkr. Rug; om en Mand i Hundebøl siges, at 3 Koer er taget fra ham og bragt til Gaarden (Gram). I 1687/88 har Th. Rasmussen til Reparering af Gaarden faaet anvist af Goclset Trae til 9 Stolper, 1 Bjælke og 8 Sparrer; hertil er beregnet 4 Ege til Stolperne, Bøgetræ til Resten. I samme Regnskab har P. Nielsen faaet 5 Traver Straa til Straatag, men omkring denne Tid, 
formentlig forst paa 1688, giver han op og render fra det hele. Der foreligger herom følgende Auktionsopgørelse (med Kobernes Navne):

"Peter Nielsen, Kempsgaterl ar Anno 16x lebet derfra, har ofterlant

1 Hest, lansmus Rasmussell

1 yammel, Peter Skolemester

It : 1 Fwl, Jens smed

1 Ko, Ritsmus Rasmussen

1 Hest, Jesper Thomsen

1 Ko, Niels Rasmussen

2 Kvier staar hos Niels Rasmussen."

3 Rall.

20

$3 n$

4 .

4 "

1 "

Efter Regnskabet for Maj 1687- Maj 88 skal Th. Rasmussen for sin halve Gaard betale 12 Rdl. 36 sk., mden anden halve Gaard har han dette Aar frit火. Den forladte halve Gaarl gaa derefter over til Thomas Rasmussens søn soren Thomassen.

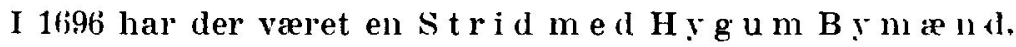
der havde forhindret, at Kjemsgaards Kreaturer græssede i Hygum Enge, hvorfor Sagen kom for Fros Herredsting, idet Herskabet paa Gram, repræsenteret ved Ridefogden Jep Ebbesen, vilde' godtgore, at demne Græsningsret var udovet saa langt tilbage. som Folk kunde huske, og at der derved var vundet Hævd derpaa. For Bymændenes Sag optræder Kongens Ridefoged, fordi Bymændene hørte under Kronen. Tingbogen indeholder on sagen folgende:

Torsclagen dend 25. Juni 1696.

for Retten fromkom velacht. Jep Ebbesen af Vesterlimest, som efter lovlig Kald og Varsels Gifvelse, begiarer paa Hendis lloygreflige Naadis Vegno af Gram, sino inclstefnede Vidner i Da: afhort; da forst fremkom Peder Shotter af Brendstrup og kunrlminulis urli - 40 Aal, da el det hannem fuld vitterlig, at Kiembsgaarls Kratter (Kreaturer) gick ulast- og ukicrt i Væaster BeckEnge, lzidefogden suarede hertil, at Jep Elbesen s'atte Peder Shotter, self ordit i ordit, ydemehre urisiger Peter Shgtter, at for-nte Kiembsgaards Kretter altid gick ulast og upaa- 
kiert i for-nte Enge, fra dend tid dend forsto grosle vaar afbiergot. Hvorpan Peder Shotter giorde sin Ifelliganurls Ed, saaledes i sianched at vahre. Noch fremkom Christen Malsen af lBrendstrup og vandt (- vidmede), at hand kunde mindis ofver .7) Aar, da gick Kiembsgadritz Kratter iblant Hygom Kretter, altid ulast og upaakiert, efter at dend forste cirole valr afhierget, eftersom hand har ticnt i for-nto Kiemlssanard, hrorpan, hand gior(le sin Hellig Aands Aa med upholden finger. Noch fremkom Jens Nielsen af stor Knorborg og vandt, at hand for - 21 Aar siden tiente peder Nielsen, da hoenolis i Kiemusgaard udi 1 sar, samme Aar tog vahr paa hats Baster, og da forbol sin Hushond hanmem, at hand ingen shade motte Larle giore i Hygum Enge, del hosz Kiembsgaards (irumb heligende, saafrembt hand iche self dertill vilcle svare og unclgielde, niens dot vaar hannem og vitterlig. at Kiembigaarolto Krarter altirl imialertid, efter at Ifgroden vaar aflierget, gick ulast og upaakiert Kiembsgaards Kratter ved Hygum Kratter, hvorpar Jens Nielsen giorde sin Helligaands Ad, udi Heede og Mose, Norden Hygum Nimback; Herpaa fremkom Marcus Anclersen og sin Hustru af Brostrup og udsagde, at dennem gandske intef vaar beevidst on Kiembagaurltz fagang. Hernast fremblom $\mathrm{Nis}$ Tammesen af Hygum, og efter Sporsmohl af Jep Ehbesen, wandt, at di af synder Olling $i$ forige Tider gaf til Hygun Grander en ${ }^{1} z$ tyncle oll eller en tynde fll till minde (Verlerlag) for deris Fagang i Hygum Ifele og Mose, nens ivhe hand widste nogit om Kiembsgaardtz fagang, videre end at di af Kiembsgaard, naar di af Kiembsgaar, leris Kretter kou Hygom Mænd for nær, og di af Hygum iche vilde Lade det gaa langere, motte di af Kiembsgaard holde det derfra, og vandt at hand let simmis kunde mindis udi - 60 Aar, hvorpat Nis Tammesen giorde sin Helligaands Æd.

Noch irettelagle forb-ne Jep Ebbesen af Vesterlimmet, som fuldmagtiger af Hindis Høygräfflige Naade, og i Retten frenlagde en skriftlig Missive, Lydendis Ord for Ord som følger: 
"Velardle, Hoytachthahr og Hoybetrocle Hr. forvalter, Hnytærede, fornehme Ven og Velyndere. Paa Hans Begiaring till mig, om min ringe Inderretning, Kiembsgatrolis faclrift angaaende, er dlenne min sandfardigo Tienstlige Berattelse, at jog icke veed eller kand mindis, at Ifullis Hoygrefflige Naades Tndersaatter i Kiembisgard sata lange jeg her vod stedet, nu offrer - 40 Aar har varit, er nogen Tid efter Enghiergningen af granderne her i IIygum bleven forment, at driffye med deres Quag paa Hygum lieckenge. Kiombsgaarls marck angrensencle, hvorfor ald dencl Hinder og Fortrexl, som Inndes Haygrefflige Naadis Cndersanter paa bemelote Kiembsand udi deris faredrift nu paa nogen tid er vederfaret, ey allone urlen, men enclog gandske imod min villic og Samtocke er skend, Hvilcket iex tienstarbmligst had Veladle $\mathrm{Hr}$. forvalter, at matte Hendis Hoygrefflige Naale, min Hoygunstiga Patronesse insinueris og ieg ned mit linge Hus Hendis Hoye Patrocimo ydmygst recomenderis, som stedste forbliffver Hendis Hoygrefflige Naadis trohiertigo forboler og allerydmygeste Tienst, saavell som veladle Hr. forvalter, min Høytærede Velynder tienstarbndigste

Hygom Frasteganal d. 19. Juni 1696.

Peder Jacobsen.«

Jacol Jensen af Hygom motte i Retten og hegiarede, at Harderlig Hr. Peder Jacolsen motte ouffershreffne Missive bekrafte verl $\sin$. Isl pala sine Tillhorlige Stoder, og vede (?) Jep Eblesen paa Henclis Iovglefflige naarlis Vegne og windo her offer, og Hans Hansen af Hygom paa Samme Hygom mands Vegne, hegiaererle gienpart Heroffver, og vilate saa suare hertill $i$ dax otte - eller 14 I)age, og stod Parteme i Dag med hver ander til werlermahl.

Torshagen dend 6. Augusti 1696

flemkom i lag for Retten Kongelig May-tts Ridefogit Joachimus Wachatius paa rodlinggaard og efter Loulig Kald og Varsels giffvelse, begierede sine indstæffnede Vinder Loulig afhørt, da eftersom Herritsfogilen Holt Vinrlerme louwhogsarlen forre, forst 
frenkom Bertel Nissen af Frsted $n g$ kuncle Mindıs udi - 60 Aar, sa a længe siden hanıl kom till Fasted, da først udi velbyrrlige Hr. Detleff Bockwoldt till gram laans ticler, Lod hand Kiembsgaards Auffling selff Auffle, og da imidlertid, kand hand mindis, at Kiemlssgaards Kretter gick norden Jegelunds Beck, paa Heedle, mens icke hand nogen tid vaar heviist, at Kiemlsgaards Kretter gick urli Hygom Enge og marck, synden dend Breck, og Ligesaa udi velbyrdige IIr. R. Marskals tid lod dend volbohrne Herre ogsaa auffle Kiembsgaards Auffling og da irnidlertid gick Kiembsgaards Krettar altid norden for-ne Jeggelunds Brok par Heeden, mens iche hand vidste, at det nogen tid gick udi Hygom Enge og Marck, hrorpaa for-ne Bertil Xissen medl upholden finger giorde sin Heliigaands Ed. Hvorefter frembkom Klavs Jensen, Jep Lauritzen, og Perler Nielsen aff Fasted, di Samtligen vanut, at for $(=$ for $)$ siclste Schwenske Tid, ungefæhr for en - 37 Aar, vaar dennem i Guds Sandhed bevidst. at for samme finders (Fjenders) tid, saa længe di kunde huchse. kom ermelte Kiembsgaarls Kretter j৫ke nogensterls i Hygom Enge, ved Becken, hvorpaa de med deris uphollne finger giorde deris hellig Aands Ed - hvornast fremkom Niels Andersen af Hygom, halnefolt i Hygomby og kuncle mindis, at udi sine ungdoms aaringer, vaar lannem vitterlig, at Hygom Mrend for tog Kiembsgards Kretter incl, mens hvor de tog rlet, vaar hannem ganske intet leviist, samme vaal kort for for-nte finders till, naar vaar Niels Andersen inttet beviist, hvorpan Niels Anlersen giorde sin Helligaands Ed med sin upholden Finger.

Kongel. May-tt Ridefogit tillspurle samptlige Hygom Mænd, saa mange som efter Loulig Kald og Varsel her i Dag vaar tilsterle, som vaar Ial's Jürgensen, Hans Hansen, Lyrlick Hansen, Soren Staffensel, Mads Anclersen, IIans Jensen, Knud Madsen, Peder Jepsen, Togger Jensen, Jacol Jensen og Nis Tammesen, alle aff Hygom, eftersom haade Back Enger vaar Blode enge og iche kunde taahle Frollift, paa det at di samme enge iche skulle forkvarkis, og der auffer Kongl. M.: grund skulle Ruineres, om di holt diris egit Kretter fra samme Enge, hvilcket di sampt- 
ligen svarede, de forbygler deris Hyrde at hand ingenlund, shall drifve nerl deris Kretter i for borle Enge, uden de for hannem aff vanwahr derudi kand komme, hvorpaa de samptligen dend emme efter dend anden, med deres upholden finger giorde deris helligaands Æal, hvorpaa Kgl. May-tts Herritsfogit raabte 1., ". og 3rlje (rang om Nogen efter Kald og Varsels giffvelse noget hertill haffle at svare, mens icke nogen svarede, og begierede Kongl. May-tts Ridefogit Thingsvinde herover, og stodt Kgl. May-tts Ridlefogit og Jep Ebbesen af Vesterlinnet paa Greffindens Vegne af Granı med hverandre till Vederunahlsting. -

Tingbogen melder intet om nyt Retsmøde, og Hygum Mænd er saaledes gaaet af med Sejren.

Bagved denne Sag har sikkert Ths. Rasmussen staiet; han synes at have været en Mand, der vilde have Ordell og Ret i Sagerne. I 1703 stævner han saaledes 7 Vidner for deres Sandhed at vidne »om hvis Oufferlast Olluff Jenssen i Knorborig forøffrede imod Tammes Rasmussen i Kiembsgaard Fredagelı den 27 . Juli sidst afvigt paa Vejen som lober neder till Kiembsgaards Enge«; hvad det var for Over!ast, faar man ikke at vide, idet de to Naboer næste Retsdag møder som forligt: Oluf Jensen betaler da 4 Skil. "til Retshusets Reparation«. - I en stor Proces i 1701-4, hvor Præsten i Rødding overfor Chr. Jessen, der i 1698 havde solgt Langetvedganrd, holdt paa, at 2 Ottinger deraf var Præstens Annexjord, som altsaa ikke kunde sælges, medens Jessen hævdede, at Jorden havde ligget til Gaarden i ca. 150 Aar, og at Præstens Ret kun bestod i 10 Skp. Rug og 12 Skp. Byg aarlig, vidnede Ths. Rasmussen, at da han omkring 1684 forhandlede om Gaarden, havde den daværende Ejer sagt "7 Ottinger vilde han sælge hannem og dennem til hannem forskøde, mens 2 Ottinger hørde Præsten i Rødding till, dem vilde hand intet have med at bestille«. Jessen indvendte, at man ikke kan vidne efter en død Mand, og at vedkommende Mand var Mindremand, da han i 16652 Gange var med Lov og Ret forvunden og lovfældt, uden at have faaet Oprejsning af $\mathrm{Kgl}$. Majestret, hvorfor Præsten heller ikke vilde 
kaste Jord paa hans Lig, da han var død; en saadan Mands Ord kunde derfor ikke gælde. Men Jessen forfulgte ikke denne Indsigelse $i$ de foreskrevne retslige Former, og han tabte Processen. Han maa have tillagt Ths. Rasmussens Vidnesbyrd stor Betydning, idet han derefter indstævnede ham særskilt. Ths. Rasmussen erklærede, at han ikke havde vidst, at omtalte Mand var Mindremand, men iøvrigt udeblev han fra Retsmøderne og blev derfor dømt til at betale Jessen Sagsomkostningerne ved dette sidste Søgsmaal; iøvrigt afvistes Sagen. Mulig har Ths. Rasmussen ved Udeblivelsen handlet efter Ordre fra Godsherskabet, idet han ogsaa sagde, at han skød sig ind under dette. I 1706 indstævnede nemlig Kongens Ridefoged forskellige "Gl. Grammere" til Klaring af deres Tingpligt til Herredstinget. Her mødte da Ridefogden paa Gram og erklærede, at de "Gl. Grammer" er Grevindens Livegne og Vornede, hvorover hun har Hals og Haand, hvorfor de ikke er tingpligtige. Tingprotokollen for 1707-17 mangler, men i 1712 fik Gram Gods sit eget Retsting.

Søren Thomassen synes at have haft Uheld med sig ligesom Forgængeren; et Uddrag af Godsregnskaberne for 1687-92 viser, at Ths. Rasmussen intet skylder, Sønnen derimod 31 RdI. 12 Sk.; dette Beløb eftergives til 14 Rdl., men i 1699-1700 har han ell Restance pai 28 Rdl., Faderell derimod kun 6 RdI. 4 Sk.

I disse Regnskaber er Fæsternes Ydelser omsat i Penge, baaile for de Husdyr, der tidligere kunde leveres, og for den afleveringspligtige Rug og Byg. Dette var forøvigt en almindelig Udvikling, idet Priserne gennemgaaende havde varet stigende, og Fæsterne derfor saa deres Fordel ved at kunne afhænde deres Kreaturer i fri Handel i Stedet for at aflevere dem til Herskabet til en lav Beregning. Medens Peter Nielsen faar godskrevet $1 \mathrm{Rdl}$. for et leveret Svin, maa efter samme Regnskab (1679-80) Fæstere, der ikke havde Valget mellem svin og Penge, betale 1 Rdl. 3 Mark for at være fri for at levere Svin. Godset holder for disse sidste Fæsteres Vedkom- 
mende fast ved Retten til at faa Dyrene leveret. De brugtes i Husholdningen eller solgtes i røget Stand; i 1670 leveredes saaledes 28 Landgilde-Svin; i fri Handel synes Prisen at have været 2 Rdl. pr. Stk. Iøvrigt synes de aarligt leverede Dyr at være: 23 Faar, $23 \mathrm{Gæs}$, 90 Høns (og $90 ~ Æ g$ ) fra de hoveripligtige Bønder ("Trælbønderne«), hvortil kom 35 Svin, 22 Høns og 22 Eg fra Fribønderne (ikke hoveripligtige). Derimod synes Udstaldningen af Øksne at være afløst med Penge; et Brev fra Aug. 1669 synes (som en Undtagelse) at bekræite dette: "Tro ikke, at jeg kan beholde alle Studene paa Gaarden; der maa nok fordeles en Del til Bonderne, da Straafoderet er alt for ringe«. I 1712 beholder Bønderne selv $28^{1 / 2}$ Svin og maa derfor betale 2 Rdl. pr. Stk.

Fra 1700 synes de 2 Bønder atter at kumne svare Afgiften. I 1701 dør Søren Thomassen. Da der efter Kirkebogen holdes 2 Bryllupper paa Kjemsgaard dette Aar, synes det som om de 2 Halvgaarde er gaaet over paa nye Fæstere, hvoraf Hans Pedersen er gift med Th. Rasmussens Datter Karen Thomasdatter; den anden er Kr. Matzen fra Jernved, gift med Ane Nisdatter fra Kjemsgaard. Hendes Tilknytning til Gaarden kan ikke ses. Efter et Regnskab (udateret) staar disse 2 Mænd opført med hver $1 / 2$ Gaard. Hans Pedersen nævnes i Kirkebogen ogsaa Hans Pedersen Blytrækker eller Hans Blytrækker og har ogsaa efter it være kommet til Kjemsgaard drevet dette Haandværk, som Gram Godsregnskaber viser:

1709 7/R: Blytrecker Hans Peder'sen for at lægge Bly i en Rende 6 Sk.

- 4/12: Hans Pedersen af Kiembsgaerd for Ronderne paa Taget at omstøbe og forfærlige 32 sk.

En Rasmus Thomassen Blytrækker, der nævnes i Gram: Regnskab for 1729, har formentlig været Thomas Rasmussens Søn Rasmus, der har lært Haandværket hos Svogeren. Om Thomas Rasmussen har været den ledende Kraft hjemme paa Gaarden under Svigersønnens Fraværelser el ${ }^{\mathrm{e}} \mathrm{er}$ om dennes Kone Karen, der fik en saa lang Levetid paa Gaarden, har va- 
ret den styrende, ved man ikke mere. Thomas Rasmussen nævnes i Skovregnskaberue som Køber af Træ, og han har nok haft den gamle Driftighed i Kroppen, hvad enten han købte 'Træ til Gaardens Brug eller' til egen Virksomhed i Aftægten:

22/10 1705: Thomas Rasmussen fra Kämbsganrd for en omfalden

Bøg (i Skjoldager Skov)

8/12 1705: Et gammelt Stykke Bøy

senere samme Aar: En Boy

1708: Thamas af Kinmsqaard betalt for 2 stk. Egetræ 1 Rdl. 16 Sk. betalt for et gl. Stk. Bog 1 -

Ved et Tilfælde findes hans Navn ogsaa i 1712:

Indtægt 6/7 1712: Tomas Kiemsgaard betalt Mølleskylden for Ao. 1711, nemlig 6 Skp. Rug à $10 \mathrm{Sk} .=1 \mathrm{Rdl}, 12 \mathrm{Sk}$.

(NB. hvilket tilhører Mølleren og hannem igien bør betales).

Vdgift: Betalt Hans Moller for Tomas Kiemsis Mølletold, som Mons. I3aggesen har optaget og beregnet Herskabet

1 Rdl. 12 Sk.

Kr. Matzen dør i 1704, og hans Enke gifter sig med Jep Knudsen. I 1706; brænder Kjemsgaard, og det synes som om Hans Pedersen herefter faar overladt hele Gaarden. Han genopbygger den selv (hidtil tilhørte Bygningerne jo Herskabet) og faar af denne Grund Frihed for Afgifterne til Herskabet, hvilket varer i 3 Aar. I 1709 - hvor Bonderne ellers klager over Misvakst og Dyrtid - betaler han sin Restance for 1705: 3 Rdl. 6 Sk. samt 10 Rdl. 10 Sk. for 1709-10, idet Herskabet efterlader ham Halvdelen af Resten (Resten $千$ Rdl. 31 Sk. betales i 1711). I September 1710 bestemmes det, at Afgiften nedsættes fra 24 Rdl. Species til 18 Rdl. (= 19 Rdl. 6 Sk. Courant), "saa længe han svarer samme rigtig". Hermed er Kjemsgaard fra at være 2 Halvgaarde a $\mathrm{t}$ e $\mathrm{r}$ e $\mathrm{n} \mathrm{H}$ e $\mathrm{lg}$ a a r d, og Landgilden kommer ikke mere op paa det gamle Beløb, men forbliver staaende paa 19 Rdl. $6 \mathrm{Sk}$.

Kirkebogens Blade fra 1709 til ca. 1732 mangler, og Godsregnskabernes Oplysninger er meget kortfattede, fordi Godset har været bortforpagtet ell Aarrække efter 1700, men Hans Pedersen er død før 1716, jdet hans Enke da er gift med Søren 
Enevoldsen. Oplysningerne er ikke mange fra denne Tid, men Fæstefolkene paa Kjemsgaard synes at have klaret sig helt godt. For 1720 noteres dog i Forpagtningsregnskabet:

Ao 1720: Mistet Manden udi Kiemsgaard baade ald hans Rugsad og 2de Plovbester, saa ieg icke alleniste ingen ulgift (Afgift) kunde bekomme, mens enclog mantte hiælpe hannem med Sxde-Korn og Fide-Korn.

Altsaa beregnes Herrskabet IClgiften ..... 19 Roll. 6 Sk.

Som Randbemærkning skriver Grevell: "De 19 Rdl. 6 sk. skal regnes som Restance for Bonden«.

I Rentekammerets Undersøgelseskommission fra Aarenc omkring 1708 siges om Kjemsgaard:

Kiemsgaard (er en Enegaurd og hạr sin Mark for sig alene).

Hans Petersen, Gammel Grammer Gaurd, ingen Ottinge.

Har sine Bygninger. Af Sad

$$
\left.\begin{array}{l}
\text { Hovinding } \\
\text { Græsning }
\end{array}\right\} \text { For } 1 \text { Gaatrl. }
$$

præstirt præstanda an seine Herrschaft.

I 1716, 1722 og 1727 siger foreliggende Besigtigelser: Er intet skyldig til Herskabet. De 3 Opgorelser giver ret fyldige Oplysninger og skal derfor anfores.

\section{Besigtigelse af Ao 1ir16}

Kiembsgaard, Søren Enewoldsen, 1 Gr., 2 Otting gammel Grammer. Har 14 fag Nyt forsvarlig Suls-Huus, som indtet manquerer. 17 fag Lade, fattes 8 Stolper, ofver Timmeret of ver ait er af Ell, Birk og Bøg og intet indwerk.

\begin{tabular}{l|l} 
& har 6 Beester \\
& 5 Kiør \\
hører Be- & 8 Ungnøder \\
sidderen & 20 Faar og 11 Lam \\
til & 1 Gries Soe \\
& Sæden 7 Td. udi alt \\
& Kand indtet Haure Salae. \\
Er indtet skyldig til Herskahet.
\end{tabular}

Besigtigelse af 1722

Kiembsgaard, Soren Enewoldsen, 1 Gaard, 2 Ott. gl. Gr. Har fæstet 1713 for 10 rd. har 4 Børn, Hans 9 Aar, Ennewold 5 Aar, Anders 1/2 Aar, Karen 8 Aur. 
Har. 14 fag god forsvarlig Sals Huus, 25 fag Lacle-Huus i tenmelig Tilstand, hører Besidderen til, efter som det Ao 1706 er afbrandt, cla de selv det igien haver opbygt.

\begin{tabular}{|c|c|c|}
\hline & & \\
\hline & Ha. & 3 Jeester \\
\hline & & 4 Kiør \\
\hline & & X I'ngnøal \\
\hline Hesidrleren & & 4 Kalfve \\
\hline & & $\begin{array}{l}\text { 12 Faar 8 Lam } \\
1 \text { Soe } 2 \text { Gries } \\
2 \text { Bitræer }\end{array}$ \\
\hline
\end{tabular}

Ligesaa
for Særlen $\quad\left\{\begin{array}{c}\text { Saapt } 6 \text { Tonder Rug. } \\ 16 \text { Ship Biug. } \\ 10-\text { Boghved. }\end{array}\right.$

Aufler ickun 10 forsvarl. La's Høe.

Deris Beester tiurer de paa $\Lambda$ ggerne og omkring ved Heclen,

Kiørne gaaer paa Aggerne og deris I'ngkreter paa Heeden.

Ieris Flave*) grauer de paa Heeden, men Moese haver do indtet. Har ingen Skau.

Irfgiften til Herskabet ej arrig 18 roll.

Til Tiende giver hand hver 15de Kierv, og af Quaget som Foll,

Lamın, Kalfve og Gries hver 1jdes Stück og ellers til Prepsten 4 Sma Brøil, en Ost og 2 Mark Smor af Koen.

Degnen farr arlig 1 S'hip Rug og 6 Sk. for 1/2 Gaas.

Er fri for Hoveri, men ey for Fgter. Haver ingen Inclgielr, men er skyldig til sine Stief-Bmin $100 \mathrm{M}$. lubsch.,

som hlifver bestaaenrle ullen Rente inclil de kommer til Skiels Alder.

$\mathrm{Er} \mathrm{i}$ det afrige hverken graveret eller honariet meere, end de andre Grammische Inderilaaner.

\section{Besigtigelse af 1727}

Gr. Grammer.

Kiembsgatrd, Søren Enewoldsens Enke, 1 Gaarl, 2 ott. Gl.

Har 4 Børn, Hans 14 Aar, Ennevolı 10 Aar, Anclers 5 Aar, Karen 13 Aar.

14 fag gorl forsvarlig Salshuus, 25 fag Larle-Huus i temmelig tilstand, hør Besidderen til.
5 Beester
26 Rill.
4 Kiør
16 -
4 Stude
14 -
6 IIngnesl
10 -
5 Kalve
2 - $24 \mathrm{Sk}$.
7 Faar og 7 Lam
4 - 32 -
Saaet 50 Shp. Rug
2 - Havre
fattes til Sad
1 Td. Biug
21/2 - Boghvede

*) flarle Herletørv. 
1 Sviin

4 Bietra.

$1-$

forleden var dode 9 Fuar og 2 Bietræ.

Er intet skylılig.

I Modsatning til de mange Gaarde, hvis Bygninger paa Grund af Forholdene i 1664 ejedes af Gram Gods lige ned til omkring 1800 (og som ved Besigtige!sen i 1722 adskillige Steder faar det Skudsmaal: Stolperne er næsten afraadnet eller staar paa Fald), har Fæstefolkene paa Kjemsgaard altsaa eget Tag over Hovedet, ingen Gæld og kan selv skaffe sig Ud'sæden. Som det vil ses, er K a r e n Th o m a s d a t t e r i 1727 atter Enke og har overtaget Gaardens Drift. Det synes som Tiderne da el blevet ringere, Opgorelsen taler om manglende Saasad, og Forpagteren af Gramgaard klager over Dyrtid (»Misvæxt og slæt Handel med Fae«). I 1728 er Enken da ogsaa ude af Stand til at svare sin Landgilde og maa laane af Naboerne mod Ret i Gaarden. Herom foreligger folgende Henvendelse og Svar:

"Hoy Edle og Velhamne Grefindie.

Som den fattige Enche Karren Tomas batter af liemsgaard Er hoy Nodtrengende for penge til Hinrles udgift indevirrende Aar, Til hincles Hoye Herskah Nemblig 19 Holl. huilke penge den fattige Enche med Hindis Egen Hielp ey kand bringe til veye, saa Hafuer hun giort Ansagning hos os underskrefunc Mand af Hiortval om bemelte penge, at blifue forstrigt mell, paa 2 Aars 'Tiill, Iluilcken vi ogsaa hende hafuer lovet Ned den condition at huis icke forskrefvne penge ved forfults Tiid hlof os higtig hetald At Velharne Herskal, vilde da tilstiode, at vi mante faa Urlarg af hendis boe, uden prosses og dom Efter I-villige Dannemænds Kiendelse, hvor udi vi Deris Høygreflige Exelentis Goef Betenckende vilde Afvarte. Erfallendis Dirris hoygrofl: Exrlentze under den Hoyestes Protection, og forblituer Drris

Hiortval, don 14. December herolvilligste

Anno 1728.

$$
\begin{aligned}
& \text { Niels Podlorsmu } \\
& \text { Niels Trgersen } \\
& \text { Hans Nissen } \\
& \text { Peder Olling.u }
\end{aligned}
$$

"Saason Niels Pedersen, Niels Togersen, Hans Nissen og Peder Olling af Hiortvarl vil forhielpe Enchen Karen Tamis-daattey. 
af Kiemsgaard med Fengenes Forskurl til hendis Afgift for judeværende Aar; da gives dennem der imod denne Forsikring, at saafremt Enchen ey til foresatte Tiid de forrestragte Penger igien betaler ovenbemelte Creditorer skal paa ansøgning urlen ringeste processe forhiclpes til fornoyelig afhetaling ved Irlvurdering i Enchens middeler efter uvillige Dannemands Patskiøn udi Gerichtsforvalterens overværolse. Datum Gram-(iand d. 16. December Anno 1728.

A. S. R. Gr. Schack.

En senere direkte Henvendelse fra Karen Thomasdatter til Herskabet udateret men formentlig fra 1732 . viser atter trange Kaar, hvilket passer med, at Tillerne nu i ilmindelighed er blevet daarligere:

\section{Hoylaname Glevinule}

Naadige Frue!

For Erlers Høj Grevelige Natale norlis jeg fattige gieldslagne Enke urli Kiemsgaard med vamodigste suk og Bon at indfalde, at saasom mig udi forgangen Aar saare stor Miscoxt paa min beste llug, saavel som paa min Boghvede-Sacl er tilslagen, det baade min sogne Prast og tvende mine Naboer udi Barsluma med mig i ciuds Sandhed Edelig kanil hekrafte, saa jeg rerover ej alleniste til min skyldig Pligt og Illgift intet har kundet salge, men enclog min Sxole Rug og Eclekorn til min og mine fattige Barns Ophold, storste Deel har og mat fil Indavlingen kinbe og borge Ealer's Нøj Grevelige Naacle derfor vilde, mig fattige nødtrængte Enke, naadigst enten efterlacle forgungen Aars Pligt eller ogsaa mig derudi san megrot forlindre som jeg af yilerste fornue kuncle taale at urlgive. Vel haver jeg af stor Nod og Trang indtaget en ung Karl af Brem til min Datter, saasom nine egne Born ej vilde eller kunile lengere tience mig for intet, og derfor tvende af dennem til fremmede uldraget, nen som samme Karl liclet eller intet tilstrakkelig til min Gields og aarlige Pligtes Betaling kand indfore, saa som hans Fader, en Enke Mand paa en fierdeparts Gaard haver 9 Born, saa hand ikkun saare lidet formaar til enhver at urgive; kand jeg i dend henseende til min anrlige Pligtes og auclen Gields Botaling dette Aar intet formal at aflegge, og hand som fornenmer, at sligt er hannem overhaanden at betale, mata norlis til merl min Datter at forlarle stectet, og jeg derover med mine mulnu uopalragne Born og allgamle Moder, som tilforn har beboet Stuvnen, at grile til Bettelstaven. Beder derfor hiertinderligst, og underdanigst, at Eders Haj Grevelige Naadle vilde naadigst udi forherorte mig bønhore; slig Eolers Hoj Grevrlige Naadis 
Mildhed og Natade vil ald Naadis Gud med timelig og revig Velsignelse belønne, hvorom jeg af min underdanigste skylrlighed sterse forblivel

\section{Høybaarne Grevindis inderlige forbedere}

Karen Thomasdatter.

Svigersønmen Peder C h r is ten s e n blev gift med Maren Hansdatter i 1732. Hans Tid paa Gaarden synes at have været en stadig Kamp for at svare, hvad han skulde. Frederik d. 4.s sidste Regeringsaar betegner jo iøvrigt elendige Kaar for den danske Bondestand. I 1733 laante Peder Christensen ifølge bogført Obligation af sin »kiere Broder Soren Christensen af Brem til min høy nodvendig Brug og øvrigheds Udgifter« 40 Slette Daler mod Pant i Kjemsgaard og "udi anden min Midler og Boehave, vare sig levendis eller dodt«. I 1736 er han i Restance til Herskabet for 30 Rdl. 46 Sk. I 1738 betaler kan ikke Afgiften fuldt, nıen kun 10 Rdl. 6 Sk., hvorom folklares i Regnskabet:

Formedelst hand nu sidste Vinter ved ulyckelig Handelse har mist 3de Baster, kand han umueligt urlen Ruin hetale den resterencle Afgift, og clerfor heder om Dilation.

I 1737 døde hans Kone, og der oprettes følgende Dokument af Hensyn til deres Børn og Svigermoderen:

Som Perler Christensen udi Kiemsgaard hans Hustru na Salig Maren Hansit ved Ioden er afgangen efter at de ucli .Egteskab har sammon aulet Trende Barn naunlig Christen Pedersen 5 Aar gl., Hans Pedersen 4re Aar gl., Søren Pedersen 11/2 Aar gl.. saa er foreening treffit imellem ham og bemeldte Hans Sal. Hustrues Brodre Naunlig Hans Hansen og Thomas Hansen verende udi Kiemsgaard samt Peder IIansen, der har tilhold udi Sxd, paa dend maade, at hand holder for-nte hans Jorn til Skirkelighed og forngden Skolegang indtil de bliver Vel underviste udi Lasen og Skriven, saa og ved forsvarlig opdrat af Fødo og Klæde til de hliver 18ten Aar gammel, skulle de icke saa have Lyst til at blive lenger hos Farleren giver hand den forsvarlig Klader af I'llen og Iintien forend de konmer til fremmede, saa og giver hveer en Fuater og fude dend een Aar, foruden er der tillagt deres Sal. Moders Skrin og Vefvel, som de deeler imellem demmen. (Ig som hans Sal. Kones Moder Karen Thomas- 
datter forhen har Beloed forben-te Gaardspart Peder Christensen er overdragen, saa er der foruden med hende og forberorte henlis Born aftalt, at hand skal forskave hende ophold og forngden Husvarelse hendis Livstid som af hannem altill forsvarlig ved lige holdes, foruclen ullagis forn-te Encke Aarlig Land til 2 Skipper Sard, som hand forsvarlig dyrcker lliver og Hiembierger, saa bliver hum og tillagt dend Vester Ende af dend Vester Eng efter denal Øster Holkrog - hende aarlig hiembiergis - lige som og formbilen Ildelland hver Aar forskave neml. 16 La's-Torv. forskuver og verlligeholrler Peder Christensen hans Kones Mocler ren goed lioe, Levinclis og aldrig cloe, forsvarlig, og om Sommer med Grasning-Kircke og Molle Vogn skavis hende, naar hun det forlanger og forngilen finder saa og ved dorlelig Afgang lader hendis Liig skickelig til Jorden Bestarlige, imod at Peder Christensen nyler hvis hun sig efterlader undagen hendes Livsklæler og Tvende Faar de zde hendes Ionttere antager og beholder ..... Datum Kiemsgatard (l. 17. Febr. Anno 1738.

Peder Hansen, Thomas Hansen, Hans $H$ H S Hansen, Peder Christensen, Karen Thomastatter.

Navmemerck

Peder Christensen gifter sig atter i 1738 med Jeng Pedersdatter fra Knorborg.

Fra 1740 foreligger en til Herskabet afgiven Erklæring om hans ulykkelige Forhold - formentlig for at faa Udsættelse med Landgilden - den lyder saaledes:

Som nax rerende Peder Christensen af Kiemsgaard har vært hos undelskrefne voris Sanclherls Attest ogvidere Begierenlis angaaencle dend Skande og ulychelige tilfælde som hand paa Beester Kuer og Andet Smaaqueg siden hand kom til bem-te Kiemsgand at boe lar tilslaget, da el det voris Sandfardige Virlne og Beretning, at bem-te Peder Christensen tirl efter anden har mist hatade Køer, Beester og Kalfve som skulle varet til Nytte og opclrat og sarilelis i afvigte Aar 1739 har hand mist og er hortclucl for ham 2 Heste og 1 Iloppe, di 2de af 3 Aar gammel og dend Eene 5 Aar gammel tilmed len bedste Koe, for uden at hans Rug forleden Sommer tog stor Skarle af Natfrost og Riimen da clot clrielle of $\mathrm{i}$ indeverende Aar for kort tid siden har hand mist lend bedste Koe som han haffle som var med den tredie half, hvilket i ald Sandher ogvidere merl Fal kunde bekræftes on fornorlent giøres.

Knorhore Niels Klausen
Peller Ollesen


I 1741 laaner Peder Christensen 70 Rdl. af "velfornemme Mand Anders Matzen (af Abitskjær) til min høye Herskabs Udgifters Afbctaling, saavel som anden privat Gield«. Ved Tinglysningen af denne Obligation udslettes Panteforskrivningen paa 40 Slette Lalere til Broderen.

I 1745 havde Kvægpesten raset her som andetsteds (i hele Danmark regnes at være bortdøet 249,000 Stk. Kvæg), og det var i Forvejen slette'Tider, hvad Tingbogen for 1744 viser: Den 30. 1. 1744 udstedes Stævning mod 61 af Granıs Fæstere, derunder Peder Christensen, for skyldige Afgifter for Aaret 1 i43.

De skyldige Beløb varierer fra 1 til 30 Rdl., men de fleste ligger omkring 2-6 Rdl., Peder Christensens Restance er 6 Rdl. 44 Sk. De foretagne Udsættelser af Sagen gav lidet Resultat, og 16/4 dømtes 50 Fæstere til at betale Restancerne herunder Peder Christensen 7 Rdl. 22 Sk. - inden 15 Dage og i Tilfælde af Efterladenhed at have deres Fæste forbrudt.

Nu maatte Restancen jo betales, hvilket ogsaa sker, maaske ved nyt Laan (hos en Broder?) eller ved at sælge bort af Besætning eller Indbo, men for 1746 er Afgiften atter ubetalt. Peder Christensen døde snart efter, vistnok først paa 1747, og tla var han "kommet ganske tilbage«, og Dødsboet erklæredes fallit, hvorefter Herskabet overtog Gaardens Administration indtil Auktion afholdtes d. 28/3 1748. I Godsregnskaberne nævnes for 1747 Knud Knorborg (Forpagter ?). Han laaner til Sædekorn hos Herskabet:

22/4: Havre 4 Td. a $5^{1 / 2}$ Sk. $=3$ D. 32 Sk.

20/5: Byg 1 Td. 2 Skp a $10 \mathrm{Sk}=2-4 \mathrm{Sk}$.

3/6: Boghvede (Gram) 1 Td. a 11 Sk.

" (Seekamp) 2 Td a 12 Sk.

Senere nævnes Peder Thomassen.

Udkastet til Auktions-Vilkaarene er bevaret og lyder:

Conditioner, hvorefter Kiemsgaard med videre til den Huystbydlende til fæste paa Livstid overlades:

Kiemsgaard med den derpaa staaende Bygning tilligemed ald Grunden af agger og Eng, Hede, moose, samt alt anclet, som rler- 
til inden og uden Marcken Skiell laegger og af Arilds Tid lagt haver, med den i Gaarien hefindente IRugsad, Giødtning samt paa Stedet nærværencle utærsket Korn af alle Slags, saa vel som Hret, de trende cler varende biester, med en graae hoe og Stuclling, overlales den Hoysthylende til feste paa sin og Hustrus Livstill.

2. Den sædvanlige tiende til Kirchen, Kongen, Herskabet og Præsten svarer den Hoystbydende aarlig og upaaklagelig til velkommencle.

3. Kiøbeskillingen betaler den Høysthyclemde paa Gramgaar til Hr. Oberinspecteur Lehman ugen efter auctionens datum.

4. Den aarlig Afgift, Faste og Lanclgille 20 Rixclaler Cou. hetaler Besiclderen paa Gram til hver Martini. 5. Fastet 20 Rixa. erlagger den Hoystbydende tilligemed Kiøleskillingen mod Fastebrevets Erholdelse.

fi. Inen Kinbende staur fust for sit bud og derfor paa autionsStedet stiller Caution om forngrent eragtes.

7. Fra Auctions Datumen antager den Foystbydende Gaarden og dertil hliver ansvarlig, saasom den fra den Tid staar for han: Regning og Risico.

8. Peder Enevoldsens Enke, som er til Aftegt der paa Stedet, forbliver der frembleles paa hendes Livstid og nyder hvad aftagts Contracten formelder, med mindre den Hoystbyclende anderledes med hembe derom kand i mindelighed forenes.

9. Gaarden tiltrerler den Hoystbydende frie for ald restance af Skatter og Landgilie, samt ald anden paa Gaarden og Sterfboet haftende gield til datum.

Ingen bud antages Ringere end 2 Rixd.

Hvad der efter Kvagpesten og anden Ulykke var tilbage ved Auktionen og om dennes Resultat, fortæller Protokollen fra Auktionen 28/3 1748: Løsøret, herunder 1 Ko, 1 Galt, 2 hvide Gæs og 1 Gase, indbragte ialt 26 Roll. 10² Sk.

"Desforuden er Kiemsgaards Ganrd sig selv formelte 'Tid solt paa offentlig Auktion til Yver Jes persen fra Harrebye for dend Suma 90 rd.«

Som Kreditorer fik Broderen Anders Christensen i Brem 10 Rd. og Ander's Matzen af Abitzkær 70 Rd. Til Herskabets lordring, 66 Rdl. 12 Sk., var der altsaa ringe Drkning.

"Formedelst Stædets slette tilstand " blev der forund Iver Jespersen "Frihed for AEter i 3 Aar, derefter forretter ha॥ Korn-Agte og ingen andre som hans Folmand «. 
Foruden Karen Thomasdatter (fejlagtig kaldet P eder Enevoldsens Enke i Auktionsvilkaarene) -- der matte opleve ogsaa denne Skæbne, der overgik Barndomshjemmet, og som først døde i 1751 i en Alder af 74 Aar - sad Peder Christensens: Enke, Jeng Pedersdatter, tilbage fra det solgte Hjem, med 3 Børn i Alderen 3-5 Aar og dertil 3 Stedbørn fra P. Christensens 1.ste Egteskab med Maren Hansdatter i Alderen 11-15 Aar. Men dette Spørgsmaal loste sig: d. 8,5 1748 trolovede den nye Ejer sig med Euken, og d. 28/11 s. A. b'ev de viet i Hygum Kirke. Jeng var da 32 Aar og Iver 27. - Men ogsaa for den nye Besidder synes der at have været Vanskeligheder. Af de 90 Rdl. blev de 70 betalt, men de 20 betaltes forst 11 Aar efter d. 18/4 1759, og Indfæstningsafgiften 20 Rdl. var endnu ikke betalt i 1761. Iovrigt var i dette Aar betalt de arrlige Afgifter, idet en Restance paa 6 Rd. 32 Sk. for 1751 var blevet afgjort ved, at Iver dette Aar græssede 80 Faar for Herskabet a 4 Sk. pr. Stk.

Efter en Opgørelse for Aaret 1761 bestaar Byguingerne af 30 Fag Lervæg (intet Bindingsværk eller Grundmur) og ejes af Besidderen (ikke af Herskabet), de er ikke brøstfældige eller trængende til Reparation. Der ydes som hidtil i Landgilde og Frihedspenge aarlig $19 \mathrm{Rdl}$. 6 Sk., og Gaarden er fri for Hoveri og Agt, undtagen Kornægte og Tjeneste ved Hovedgaardens Reparation. Der skal stadig spindes \& Pd. Hør eller 8 Pd. Blaar. Der har varet Tale om Aflosning af denne Ydelse med Penge, hvorved Besidderen tilbød 3 Sk. pr. Pd. Hør. Der findes af Besætning: 6 Heste, 4 Stude, 5 Køer, 7 Ungnød og Quier, 12 Faar og 1 Svin. Af Redskaber nævnes 1 halvbeslaaen Vogn, 2 Trævogne, 1 Plov, 2 Træharve. Der saas aarlig: 8 Tdr. Rug, 1 Td. Byg, $1 / 2$ Td. Havre, 4 Tdr. Boghvede; der avles: Rug 40 Traver, Byg 4 Tr., Havre 2 Tr., Boghvede 8 Tr. og 20 Læs Mose- og Kær-Hø. Der findes en Kaalhave ved Gaarden, og der graves lidt Tørv, men ingen Klyne. Der drives ikke Biavl eller Humleavl, og der findes hverken Jernovn eller Bryggerkedel. Paa den anden Side er der ikke Gæld paa Ejendom- 
mell, udover Fæsteiudløsningen, der aabenbart ikke har trykket Besidderens Samvittighed stærkt.

Af Ydelserne erklæres i en Opgørelse fra 1790 af Forvalter Henrichsen paa Gram, den anforte Haand-og Spandtjeneste ved Hovedgaardens Reparation og til Møllen, Kornægt efter Tur og de $i$ en Jordebog af 1776 anførte 4 lange Agte aldrig at være blevet præsteret. I Stedet var der givet frit Kvarter og Underhold paa Kjemsgaard for Jægeren fra Gram med hans Hest og Hunde, naar han var paa denne Kant, (der jo laa ca. 1 Mil fra Gram), og en Jordebog fra 1792 tilføjer: nog han (Fxsteren) maa ogsaa besørge Transporten af Agerhønsene til Gram«.

Da Iver Jespersen gik paa Aftregt paa Gaarden i 1768, efterlod han nogle uopfyldte Forpligtelser; i 1769 resterer nemlig:

for Hovspind for 1761,1762 og 176:3

for Magazin-Transporter i 1762

resterende Afgift for 1768
1 Roll:

$$
4 \text { - } 21 \text { M. } 6 \text { Sk. }
$$

(; $-15-6-$

Dog maa bemærkes, at Magasin Transport-Afgiften staar som Restance for mange Bønder, hvilket kan tyde paa Modvilje mod at svare denne ekstraordinsere Afgift. Et Brev fra samtlige Fæstere til Grams Administratorer af 13/5 1761 lyder da ogsaa:

Hiyardle og Velbarne Herrer.

Vi fattige Underdanere udaf det hoyadle (iram on Nybel Gods er berettet af Voris Narvarende Øvrighed, at Vi skulde kiøre Kongelige Magasien fra Ekelfør (= E(:kernføhrde) og til Rensburg, hvilket er Os en umuelig Ting, Heldst i denne tid, saa som Arbedet staar nu Allermest for, Baade for Os selv og Voris Høybydende Herskab, Og dis foruden (desforuden) Havel' dend Sl.: Frue Grævinde Aldrig forlangt sligt af os, Thi hun vidste Voris Evne og Vilkor, at Vi ikke Var istand for at urlstaa slig Travalie Og Bekostning. Og Mange Her paa Nybel Gods og saa paa Gram Gods findis som Haver Hverken til at Ede Eller at Saae. Og inda det som Verer (værre er), At Basterne er $i$ for os saa Ringe i Stand, som de Nogen tid Haver været Og Aldrig dyrere, hvor Over Vi samtlig formoerler At de høye Herrer Vilde Behage denne Voris Inderdanigst Su- 
skripsion at antage, Og nu forordner en Gunstig Resolution Her over

forbliver de Hoy Gunstige Herrer Aller underdanigst Samtlige Tienere. (18 Underskrifter).

I 1759 havde tilsvarende Forpligtelse væeret paalagt de adelige Godser, men den daværende Enkegrevinde havde ladet lorva!ter Hørup paa det kun 3 Mil fra Eckernføhrde liggende Seekamp Gods besørge Transporterne for Penge, og Forvalteren mener ikke, at Bønderne er i Stand til med deres Heste at foretage den 15 Mil lange Rejse til Eckernføhrde. Hvorledes Forholdet orduedes i 1761 ses ikke, men næste Aar findes en Opgørelse over "de paa hans Kongl. Mayt's allernaadigste Befaling udi Aaret $\mathbf{1 7 6 2}$ for dennem (Gram Gods Underdanere) fra Eckernfohrde til Rendsborg*) kiørte 10 Transporter Kongl. Magazin Korn, hvilket Herskabet har ladet besørge i Tiden 26/4-20/10 ialt 450 Tdr. Rug og 630 Tdr. Havre, hvorfor Godset har betalt $432 \mathrm{Rdl}$. $35 \mathrm{Sk}$, der fordeles paa Fastebønderne efter ottingtal. Beløbet for de forste 6 Transporter androg for Kjemsgaard 5 Rdl. 24 Sk., og dette Belob betalte Iver Jespersen i Juli 1762 - hvor foruden ham kun Jens Adsersen havde betalt —, men senere betalte ejheller Iver. Det kueb iøvrigt i lisse Aar at faa Bøndergodset til at svare sig, idet der ogsaa opkrævedes en Ekstraskat fra 1762 af Hensyn til Rustningerne til den med Rusland truende Krig.

Med Hensyn til Spindepligten er det betegnende, at Bønderne (i Novbr. 1762) erklærede, at de heller vilde spinde ent betale Spindepenge, og ikke vilde betale trods Forvalterens Forestillinger om, at det ikke svarede Regning, da de med at hente Horren og bringe Garnet forsomte mere, end der behøvedes til at betale Spindepengene. Bønderne havde ingensomhelst Penge at give ud i de slette Tider. Det var daarlige Aar med Misvækst og Kvægsyge, og naar Herskabet forsogte at

-) Giransefastningen. 
skaffe Dakning ved Udpantuing hos Fasterne, viste Resultatet. at ogsaa Evnen manglede*).

Iver Jespersens Aftægtskontrakt lydel":

I den Hellige Trefoldigheds Navn

H. understadende I)ato slutet og indganet on Venlig og Kiærlig contrart imellem Iver Jespersen af Kiemsgaard og hans Stiefdatter Anne Pedlers Intter med hendes kixpeste Thams Nissen af Tornum paa Herskabets approbation som folger:

1. afstaar og overlader ieg Iver Jespersen mit paaboende og af herskabets feste havende Gaard Kiemsgaard til min kiære Stiefdatter Anne Peders Datter og hencles forhaabencles feste Mand Frlig og Velagte unge Karl Thomas Nissen i Tornum bye med alt tilbehør, det vare sig Iger og ling, Heede Krat Moose inclen og ucten Marcken Skiat, indtet deraf undtagen heller forheholden i nogen optrenckelig maader, at hand tlerpaa kand soge strixen Herskabets feste, derimod.

2. lover ieg Thomas Nissen at opsatte mine svigerformldre Iver Jespersen og sin lione Sex fag Huuset oster for Gaarden mall Ovn og Skorsten, Vinclver og Dorre for. samt det fornorine lofft Skud, hvilcket ieg hltid udi forsvarlig Stand skal holde, og til Kaalgaardjord ligeledes et Stycke irund, belegendes verl Huuset, som ieg skal holde forsvarlig uncler Dyrkelse.

3. til aftegt lover jeg mine Svigerforaldre, til deres Livets ophold aarlig fiire skipper Gronland i hver Inditagt, som jeg ligeledes skal dyrcke og hiembierge udi Rette Tider, lige saa god som mit eget Korn, men verl antagelsen skal de have det urli hver Indtagt, hvol det findes besaaet, til follor skal de (have) dend - Voster Tofft, til brandsel skal ieg give dem aarlig 26 læs, hvilrke min Svigelfader self har lovet at grave og rygte, des ligest alt som aftagten vedrorende Korn og Ho self at hierge, med hand(Haand-)arbeyde, saa lange af Gurl hannem vil blive med hellired og Sundhed velsignet, mens om min svigerfader skulde hlivo skrøhelig, skal ieg vare pligtig at drive dot hannem for-

*) Inder 2/2 1767 ansyger saaledes "Vi samtlige fattige og linge Trælbønder i Brendstrup Godset om, at nom denne Vores Begæring ej er mulig, at denne Skat maa ophøre, at Deres Velbaarenhed In vil udvurdere fra os af vores Moabilier sad meget som Dennem helager og Vi fattige Bonder da derved maa blive fri for denne. Execution, sonı vi nu ragligen imodtager, og som vi ej kan betale Fxecutions Penger, maa Vores lidet Boskaber uclpantes af tvende hirlsendte Dragoner, som ej vil lade dennem noje merl det vi bedst kunde undvare, men tager det dennem velhehager, saa vi fattige Bonder snart ikke ved enten det er Fred eller Fejcle." 
svarlig, desurlen skal jeg give demmem arrlig til IIommel og Salt Een Rttr.

4. Tratager re med sig pai Iftangt ?de Kior, som Iftagtsgiver tage forst een url, og aftagtstageren den anclen og saa fremdeles dend anden, ligeledes tager de ogsaa bre famr med sig paa Aftagten, og ren af disse 2ole Kior skal staie og gaae med paa Ageren hos Aftagtsgiverens Milcke Kocr, videre udtager de med sig paa Aftægten udaf Gaarden een Seng, en Hengskaf, den mindste Iandkiedel, een ballie og an graslee, giver dennem. nanr det kraves, een frie Vogn til Kircke, og tager deres Korn frie med til og fra Møllen, endnu skal min kiare Svigerfatler lave ud af Gamblen een liflen Sort hrogede Stud som ieg forler hannem frit nastkommende Vinter over, og siden incltet videre? Men naar een af mine Svigerformblre ved Iorlen afgaar. falder den eene skippe land i hver Indtangt tilbage til Gaurdens besidder eller aftagtsgiveren, og af det benefnte Eng faller det ligeledes tilbage $i$ saa fald fra clen oster Ende og til baarslund Holm, men naar de logge ved Drolen er afgangen, falrlor den heele aftregt tilloger til Ganmlens besidder, indtet demaf undtagen af alt hvad sig efter deres Inml forrefindes, uden min svigerfaders Livs Klader og Penge, som tilfalder hans $\Lambda$ rvinger, og svigermoders lifs Klæder skifte deres hegge Pigehorn, og een Snn skal have det Hengskal) efter dennom, i rlet ovrige Latler aftaxgtsgiveren saa vel den forste som sidste af Aftagtstagerne efter deres Inol Christsømmelig til Jorclen efter Evor hostälige.

Kiemsgaard, den 14. August 17(jx.

Hans Pedersen

Andres Ennevolisen

Tomas Nissesn

Maren Peders Datter

Ifwer Jespersen.

Peter Petersen.

At Thom as $\mathrm{N}$ issens Interesse for Skolevæsenet") har gjort ham til en forsømmelig Bonde, er der ikke tilstrakkelig Grund til at antage, thi Tiderne var daarlige. For Aaret $1769 \mathrm{er}^{\circ}$ Landgilden kun delvis betalt, og for Aarene 1770-1773 slet ikke. I 1775 finder Herskabet sig foranlediget til at gøre Bonderne et Tilbud om Læmpelser, idet der optages et Register over Restancerne med vedføjct Oplysning om de Afgifter ssom Herskabet naadigst lover at eftergive, naar det med dem (Underdaneme) anorduede, til bestemte Tid prompte betales«. Restancerne udviser pr. 31. Oktober 1774 for Kjemsgaard:

*) Han skal have varet Vinterlarer verl Omgangsskolen i Kalslund og have lavet en Regnelog. 


\begin{tabular}{|c|c|c|}
\hline Hovspind & & Rd \\
\hline Magazin-Transport & 1 & - \\
\hline lest. Afgift $1 \% \tau()-1 \% \tau i 3$, & 61 & - \\
\hline or 2 Fuster & & - \\
\hline
\end{tabular}

(Iver Jospelsen har altsaa slet ikke letalt sin Inclfastning).

Der eftergives 26 Rd. $35^{1 / 2}$ Sk.; der skal betales inden Jul 1774, Maj 1775 og Mikkelsdag 1775 hver Gang 26 Roll. 35\%². Men selv dette har nok væeret for meget forlangt. Folgende Brev sendt til "Deres hoygräflige Naade Herr Kammerherre og Greve af Schack p. p., Gissegaardt« maa vist henføres til lenne Tid. Det er ikke dateret og har ikke særlig Underskrift:

"Jeg Thomas Nissen af Kiemsgaard vilule gierne Omberle Naadige Herre om Hand ikke vilde have Taalmodighed med mig, med mine Resterende Udgifter, da Jeg Lover at Betale Dennem Til Maydag og omberler Naadige Herre at Hand vil forskane mig for Ex ec ution saalange. Thi $\mathrm{Hr}$. forvalter har haft den Paa mig og truer at hand vil tage Ham paa mig igien og forventer en Naadig I3ønhøring herover.«

Brevet er efter Sammenfoldningen forseglet med en Mont, der viser F. 5. (Frederik den 5te).

Codt var det nok aldrig i Thomas Nissens Tid, og i Begyndelsen af 1786 saa han sig nødsaget til at sælge og indlede Forbandlinger derom, hvad han iog atter har fortrudt, idet han har sat $\sin$ Lid til at kunne opnaa et Forskud og derved holde Stillingen. Men sxa synes Forvalteren paa Gram Gods at have handlet paa egen Haand. Han forklarer overfor Greven, at han har maattet handle hurtigt, da Købereu i modsat Fald ikke længere vilde staa ved sit Bud og ved en længere Ldskydelse ikke kunde skaffe »Købeskillingen«. Forvalteren anmo(ler derfor (25/2) om, at Greven vil resolvere, at den oprettede Kontrakt skal staa ved Magt, da dette er i alles Interesse; selv om Thomas Nissen skulde opnaa det forlangte Forskud, saa har man allerede set, at han kun er en middelmaadig Husholder, der næsten aarlig har forøget sin (iald ${ }^{*}$ ), og længere Hen-

*) For Tiden indtil 1781, hvortil Tinglogen findes i Granıs Arkiv, er tinglyst adskillige Laan, der stadlig vokser. 
stand vil blot bevirke, at det, der ved denne Hanclel kunde blive tilovers til Børnenes Opdragelse, ogsaa vil gaa tabt. Dertil kommer, at Herskabets Restancer ved deme Lejlighed kan bringes ud af Yerden, og som Hovedsagen, at Koberen er en god Husholder og ved Hjælp af sine egne Børn, der efterhaanden vokser til, sikkert vil sætte denne forfaldne Gaard istanit igen. Men det faldt Anne Pederslatter svært at forlade sin Fodegaard, og den 25/4 henvender hun sig til Forvalteren: hun fortryder Salget og tilbyder at lave ren Bog (i Forvalterens tyske Skrivelse: offerirt sich rein Buch zu machell) og komme overens med Køberen, naar hun selv maa beholde Gaarden. Forvalteren svarer, at naar hun straks betaler Herskabets Restancer, og der med Hensyn til fremtidige Ydelser stilles tilstrækkelig Kaution, saa maa hun for hans Skyld gerne give Ansøgning derom til Greven, men i Brevet til Greven holder Forvalteren stærkt paa, at den Ansøgning, der vil komme fra Manden, kun imødekonımes paa disse Vilkaar, "thi det naadige Herskab har til Dato haft Skade nok af demne Gaard «. Anne Pedersdatters Henvendelse fik derfor ikke andet Resultat enl hendes Mands, og Køberen $K \mathrm{n} u \mathrm{~d} J$ e $n \mathrm{~s}$ e $n$ fra Fæsted beholdt Gaarden. Næste Aar i April yder Godset Knud Jensen et Forskud paa 200 Rdl., men allerede i Slutningen af Maaneden indberetter Forvalteren, at »den unge stræbsomme Mand paa Kjemsgaard Knud Jensen i disse Dage er dod, og nu vil Gaalden formentlig b!ive solgt, da Børnene kun er smaa«. Dett" skete da ogsaa, nemlig den $30 / 81787$ til Thomas Oll u f sen. En Opgørelse vedrørende den tidligere nævnte Ekstraskat nævner Thomas Nissen som rejst fra Kjemsgaard i Januar 1787, derimod ikke hans Kone, og det kan synes, som luun foreløbig or blevet boende paa Gaarden, maaske i Aftægtshuset hos Stedfaderen, der efter hendes Moters Død atter var blevet gift i 1776 , da Kirkebogen nævner "Iver i Kjemsgaard! som trolovet og gift med "Enken Doreth i Frsted«. En Fortegnelse over de Svin paa Gram Skov, som er blevet paabrændt (til Kendetegn paa hvem Ejeren var) i 1789, angiver nemlig: 


$\begin{array}{lcccc}\quad \text { Kiemsgaard } & \text { gamle } & \text { unge } & \text { Rdl. } & \text { Sk. } \\ \text { Thomas Ohlufsen } & 1 & 2 & 1 & - \\ \text { Iver Jespersen } & & 1 & & 16 \\ \text { Thomas Nissen } & & 1 & & 16\end{array}$

En af Godsets Indtægtskilder (omtales ogsaa i 1585) var at have Svin gaaende paa Olden i Skoven mod Betaling. I 1779 havde Thomas Nissen 2 gamle og 2 unge Svin i Skoven, Betalingen var da hhv. 1 Mark og 8 Sk. pr. Stk., men fra Kjemsgaard betaltes med 3 Skæpper Rug, vel fordi Penge var knappe. I 1795, da Skovene ikke kunde føde saa mange Svin, - "Skauene ikkuns blev taxeret til halv Olden" - siger Forvalteren: "Godsets Undersaatterne er hver Skippe Rug bleven ansat for $20 \mathrm{Sk}$. og' de fremmede for $28 \mathrm{Sk}$."

Ved Salget til Knud Jensen sluttede en fra Kjemsgaards Besættelse efter Ødetiden sammenhængende Linie i Besiddernes Række. Gaardell er ikke gaaet fra Fader til Søn, men altid gennem Spindesiden. Thomas Ollufsen solgte i 1798 til H a n s J e p s e n fra Fæsted, og i denne Slægt blev Kjemsgaard i 105 Aar, fordelt paa 3 Besiddere. Fra ca. 1840 anvendtes Navnet Kjemf i denne Slægt.

Thomas Ollufsen udstedte (ligesom Knud Jensen) Panteskrivuing i Gaarden for $400 \mathrm{Rdl}$. Han havde kun Gaarden i 11 Aar og gik paa Aftægt ved Salget i 1798.

Købesummen $1100 \mathrm{Rdl}$. sl. holst. Cour. skulde betales 1/5 1798. Sælgeren medtager paa Aftægten 1 Seng og 1 Bord, 2 Tdr. Rug m. m., 2 Køer og 8 Faar, og beholder de 2 første Aar liet Aftægtshus paa $6 \mathrm{Fag}$, som staar Østen for Gaarden, med Kaalhave. Derefter skal Hans Jepsen, om det forlanges, inden Forløb af 3 Aar flytte Huset til Aftægtsjorden og bygge 2 Fag til. Til Aftægten skal høre $9^{1 / 2} \mathrm{Tdr}$. Land fra den østre Ende af Ageren, samt Eng fra den øster Ende lige nedenfor Ageren og mod Vest indtil den Hede-Brønd, hvor Bækken løber op til den nørre Brønd, og en liden Holm som ligger sønden Engen. Aftægtsfolkene har Frihed til at opbryde 1 Tønde Hedeland, men Sælgeren er kun pligtig til at dyrke 4 Skp. Land 
aarlig for Aftægtsfolkene. Disse faar aarlig 26 Læs Tørv og har Ret til nogen Kørsel, men iøvrigt faar de ingen Naturalydelser.

Det blev en længe-løbende Aftægtskontrakt -- over 32 Aar, Thomas Ollufsen døde nemlig 17/10 1830, 74 Aar gammel. Endnu lever hans Navn i Navnene "Tammeses Eng« og "Tammeses Mark " Øst for Gaarden, samt »Thomas's Rose«, en Rose, der tidligere skal have været almindelig i Bondehaverne, men nu nok nærmest findes i denne. Egn. Han skal have været en Særling og have gaaet under Navnet "Tammes å æ Hee" eller "å æ Lyng", men nærmere om ham synes ikke at være bevaret.

I 1878 gik Kjemsgaard fra Fæstegaard over til S e lveje. En Nyordning havde været under Forberede!se i længere Tid. Saaledes var der i Slutningen af 1820'erne i Henhold til nogle almindelige Drøftelser med Bønderne oin en nærmere Fastlæggelse af deres Pligter overfor Herskabet blevet udstedt nye Fæstebreve, der for Hans Jepsens Vedkommende fastsatte:

1) At der af Kjemsgaard, naar Besilforandring fincler Sted. tilsvares til den herskabelige Casse pro approbatione og i In 1 fæestning, hvad Herskabet tilkommer og Forligene desangaaende fastsætter.

2) At der aarlig til de sædvanlige Terminer betales til den herskabelige Casse 19 Rdl. 6 Sk. Courant eller 30 Rbrll. 58 Sk. rede Sølv i Afgivt med Indbegreb af Contributionen.

3) At Besidderen til lovbestemte Tider afholder de Kgl. Skatter tilligemed Bankrenterne.

4) At han aarligen forretter 4 Pund Hovspind og holder Skyttekvarter, og desforuden afholder og yder alt, hvad af Stedet ydes, afholdes og forrettes bør, samt at han fraholder sig al utilhørlig Jagen og Fisken inden Godsets Grænser.

Jordebogen for 1834 bestemmer Pligterne nærmere til: Fæsteafgift 19 Rdl. 6 Sk., Tienderug 11 Skp., Herredsfogedrug 1 Skp., Hør eller dobbelt Blaar at spinde 4 Pund, Møllereparationstjeneste i Omgang; køre 1 (Gang aarl.), gaa 1, Brandskat og Brandrenter af 24 Skattetønder, Indfæstning $20 \mathrm{Rdl}$. efter den forligsmæssige Ordning 26 Rdl. 32 Sk. +2 Rdl. i Appro- 
f.ation. Til overordentlige Udskrivninger (altsaa Ekstraskatter) deltager Besidderen efter den interimistiske Plovtal-Ansættelse af 36/144 Plove*), dog til de ridderskabelige Anliggencler kun af det halve.

Fæsteforholdet havde i Virkeligheden Karakteren af Arvefreste med Ret til at sælge og pantsætte, og i Henhold til en Lov af 1873 overgik Gaarden til fri Ejendom, idet Loven for Forliold af denne Art bestemte, at Godslierskabets Overejencomsret ophørte, og at Realbyrderne skulde afløses. Dette skete i 1878. Efter den foretagne Kapitalisering blev Forholdet, at Ejeren af Kjemsgaard skulde yde ca. 67 Mark aarlig til Rentebanken, medens denne til Greven paa Gram, Brockenhuusschack, betalte 1446 Mark, hvorefter ethvert Forhold mellenı Kjemsgaard og Gram Gods var ophørt.

Om Gaardens Størrelse haves i aldre Tid kun Udtrykket 2 Ottinge; Udtrykket Otting bruges fra Mictlelalderen og menes at betyde et Stykke Jord, der er vurderet til 1 Mark Guld. En Helgaard kuncie omfatte 2, 3, 4 eller flere ()ttinge. Helgaarden Kjemsgaards 2 Ottinge betegner derfor formentlig en stor Gaard med ret claarlig Jord. Gaardens nuværende Ejer, A. Canmmelgaard, har oplyst, at Gaardens Tilliggende, saa vidt hau ved Besked, har været ca. 200 Tdr. Land, men deraf vistnok ca. 100 Tdr. Land Hede. Hans Jepsens Søn, Niels Hansen, kaldet I.ille Niels Kjems, eller Gamle Nie's, der fik Gaarden 1830, var en dygtig Landmand efter sin Tid. Han lorl bygge 3 Stemmerarker ved Kjemsgaards Bæk, saaledes at der Aaledæmningen medregnet - blev 4 Steder til Overrisling af Engen (12 Tdr. Land). Det berettes, at Stemmeværkerne skal bave været ret dyre i Anskaffelsen, iclet Prisen i Virkeligheden indeholdt en Affindelsessum for, at en Handel om Kjemsgaard, som Niels Hansen i en løftet Stenming havde indgaaet, sku?de gaa tilbage. Niels Hansens Son Nis Kjems (paa Gaarden fra 1874) tog $25 \mathrm{Tdr}$. Land fra til Plantning Syd for Gaarden og Bækken og dannede sammen med flere andre Bønder, der havde til-

") "Plove« var en gammel Skattenorm for adelige Cortsers Jord. 
grænsende Hedelodder, Fæsted Plantage, et golt Stykke Arbejde. Derimod havde Stemmevarkerne og Hedeopdyrkningeu ikke hans Interesse og forfaldt. Da Gammelgaard i 1905 uden storre Kapital købte Gaarden, var den saaledes, at den kravede meget Arbejde for at komme i ret Kultur. Gammelgaard har opdyrket Resten af Heden og ladet Gaardens Marker overmergle i 1912 og 1913, og deme Gaard, der i Tidernes Løb har beredt de skiftende Besiddere saa meget Hovedbrud, er nu en stor veldrevet (raard, med en Besatning paa 30 Malkekøer, 40 Ungkvæg, 5 a 6 Heste og 1 Fordson Traktor til Driften (1933). Gaardens Narker er inddelt i skifter a ca. 20 Tdr. Land. Der er tilkøbt Part i Plantagen.

I Niels Hansens Tid var Besatningen 2 Heste, 1 a 2 spand Pløje-Stude, 6 a $8 \mathrm{Koer}, 10$ a 12 Ungkvieg, indtil 20 Moderfaar; i Nis Kjens' 'Tid 4 a 5 Heste samt Krer og Faar' som Faderen. Af Bygningerne er stald og Lade bygget 1914, stuehuset antagelig i 1860'erne (der er anvendt Fyrretømmer). Gaarden hai tidligere ligget ra. 100 Meter laxngere i rest.

Ved Bearbejdelsen af Osterheden var det i 1909 efter Lyngens Afbrænding synligt, at Jorden for havde været plojet, og en Karl (Thue Thuesen) fortalte ved demle Lejlighed, at hans Bedstefader havile gaxet her og plojet for ca. 100 Aar siden, efter hvad Karlens Fader havde fortalt ham.

Kjemsgaard Bak, den allerede i 1585 nævite Aa, dammes af Engkjærbæk og Hygum Nordbæk fra Hygumskov; den udmunder i Hjortvad Aa. Den nuvarende Ejer driver ikke l'iskeri i Aaell.

Hvad $\mathrm{N}$ a v n e t $\mathrm{K}$ je m s g a a $\mathrm{d}$ angaar, mener P. H. Kjems Petersen (f. 1900) at have hørt sin Beilstefader Peter Hansen Kjems (f. 184X) fortæl!e, at Kjemsgaard betød Kampestensgaard, svarende til sønderjydsk Udtale af Kampesten som Kjæmpsten, og som altsaa skulde være blevet sammentrukket til Kjemsgaard. Thøste Thøstesen i Fæsted vil dog nene, at Navnet snarere har Forbindelse med et gammelt Persomnavn. I Stednavneudvalgets Samling af danske middelalderlige Per- 
sonnavne findes intet Kjems, Kiens, Kemps el. lign., hvilket dog naturligvis ikke udelukker denne Antagelse. Nogen Afgorelse kan vel næppe skaffes, men et Grundlag for at sætte Navnet i Forbindelse med Kampesten kunde der maaske nok være deri, at Gaardens Marker har været rigelig forsynet med Sten, formentlig et Minde om Istidens Aflæsninger. Gammelgaard fortæller, at da 9 Tdr. Land af Østerheden blev opdyrket, blev der i flere Aar kart over 100 Læs sten aarlig til Ribe fra dette Stỵke.

Det skal lige nævnes, at der i Danckwerths Atlas for 1649 ved segeberg i Holsten findes anført en Landsby Kemps. Den ligger i Nærheden af Wensin, det Gods hvorfra Buchwalderne stammede. Det kunde maaske trenkes, at Ditlev v. Buchwall lar besat demne afsides Fæstegaard med en Mand fra sin Hjemegn, at deme Mand er blevet kaldt ved sit Bynavn, og Gaarden derefter efter Manden. I saa Tilfælde er Holsteneren nok snart forsvunden fra clen magre Jord, thi Kjemsgaards Fæstere har danske Navile, hvor de er bekendt fra 1585. Gaarlen synes ikke da at have ligget fast $i$ en slægt, mell nævnes $i \cdot$ Jordebngerne som undertiden bortforpagtet eller udlejet.

I Præsten Jolıs. Koks Bog "Det danske Folkesprog i Sonderjylland " fra 181i anfores: „Kæmpesgaard*) (Kæmsgaard) af Frllesnordisk Kæmpe (Hygum sogn er, som ogsaa Navnet alltyder, neget opfyldt med Kæmpehøje; sammenlign Dyshoj, Kamp og Kanptrup)«. Efter Genforeningen er Gaardens Navn i forskellige Fortegnelser fejlagtig fort som Kemsgaard, saaledes paa Generalstabens Kort. Da dette har ell officiel Karakter, har jeg henledt Geodætisk Instituts Opmærksomhed paa Forholdet og overfor Henvisningen bl. a. til, at Gaarden soprindelig hed Kempisgaard i 1649 « bemærket, at dette Udtryk kun findes i Danckwerths Kort og ikke er i Overensstemmelse meil den samtidige og senere Skrivemaade, der svarer til den sonderjydske Udtale Kjemsgaard, ligesom at den Slægtsning.

*) Denne sjæline Stavemaade mala vist staa for Koks egen Reg- 
interesse, der ligger $i$, at Gaardens Navn og slægtsnavnene stadig er overensstemmende efter disse Navnes Slægtskab, turde veje saa tungt, at der ikke blot ikke skulde vare nogen Betænkelighed ved at blive ved Gaardens gangse Navn, mell at der overhovedet skulde stærke Modgrunde til for at forulempe en siadan fremført Interesse. Tiden naa saa vise, om Instituttet har Forstaaelse for dette Hensyn eller mener at kunne ændre Gaardens Navu efter en eller anden Retskrivningsregel e. 1 .

I I. A. Markussens lille Bog "Optegnelser fra Lintrup og Hjerting Sogne« staar anfort:

Syd for Dover, ved Landevejen til Howling ligger en stor Bondegaard, kaldet Kjemsgaard, hvis Jorder for storste Delen er taget fra Nissumgard.

Dette nye Eksempel paa en Kjemsg.lard maa imidlertid bero paa en Misforstaaelse, idet den paagældende Gaard efter ell gammel stedkendt Mands Udtalelse aldrig har haft dette Navn.

Paa Villenskabernes Selskabs Kort for 1804 skrives Kjemsgaard "Kimsgaard«, og med samme Navn staar tillige angivet en Gaard, der er beliggende mellem Gram Aa og Ganderup. Jeg har ikke i anden Forbindelse truffet pai demne Gaard eller ved noget om dens eventuelle Forbindelse med KjemsSlagterne.

\section{Fæstere og Ejere paa Kjemsgaard.}

Listen angiver alle Besiddere fra 1706; før dette Aar er den ufuldstrendig. Hvor Overtagelsesaar kendes, er anført "fra«, de øvrige Aarstal betegner, at vedkommende Besidder ses at have haft Gaarden i dette Aar, medens Overtagelses- og Fratradelsesaar ikke vides.

1585 Jens Sorensen

1599 Niels Jensen*)

*) Et Dokument fra 1599 nævner som "Adelens Tjenere« i Hygum Sogn: Nis Thussen og Peter Thussen, Mats Iffuersen og Niels Jensen. Den sirlste er formentlig Jens Sorensens Søn paa Kjemsgaaril. 
$1625-36$ ubesat?

1656 Thomas Hansen

1659 Hans Kjær

1663--li8 Øde (vistnok 1659-73)

1673-88 Peder Nielsen

1683-1701 Thomas Rasmussen

1688-1701 søren Thomassen

1701-1710 Hans Pedersen Blytrækker

1701-1704 Kr. Matsen

1704-1706 Jep Knudsen

1713 1722 Soren Enevoldsen

1727

$$
\text { do.s Enke }
$$

1732 Peder Christensen

fra 1748 Iver Jespersen

" 1768 Thomas Nissen

"1786 Knud Jensen

" 1787 Thomas Ollufsen

" 1798 Hans Jepsen

" 1830 Niels Hansen

"18\%4 Nis Nielsen Kjens

" 1903 Fr. Rysz

"1905 Anton Gammelgaard. 